\title{
Introduction to Libertas and Republicanism in Renaissance Bologna.
}

\section{Angela De Benedictis}

Storicamente, 8 (2012).

ISSN: 1825-411X. Art. no. 17. DOI: 10.12977/stor555

This dossier contains three papers presented at the Annual Meeting of The Renaissance Society of America, which took place in Washington, DC, 2224 March 2012.

As usual (www.rsa.org), about nine months before every annual meeting, scholars are invited to submit for review individual papers or full sessions to the Program Committee. The panel Libertas and Republicanism in Renaissance Bologna was submitted in June 2011 and accepted in September 2011.

[[figure caption="Achille Bocchi - Libertas Populi Bononiensis" width="120px" fancybox="true"]]figures/2012/debenedictis_libertas/debenedictis_libertas_2012_01. The form in which they are proposed now to the readers of "StoricaMente" is substantially the same in which they were presented in Washington, where, according to the conference norms, they were limited to a length of twenty minutes.

In this dossier only a few quotations, short textual notes and essential bibliography have been added at the end of each paper. This material, which is not communicable in an oral report of twenty minutes, was then distributed to the participants in the panel by means of a handout.

The three papers were presented on March 23, 2012. Introduced, as usual, by a Chair (Nicholas Terpstra, University of Toronto), they were then 
discussed by a Respondant (Julius Kirshner, University of Chicago).

The program remains visible at the site of The Renaissance Society of America , p. 337.

To the issue of "civic republicanism in the early modern" "Storicamente» has already dedicated some space with an essay by Nicholas Terpstra, which was the extension of a paper given at the 2006 annual meeting of the Renaissance Society of America, held that year in San Francisco[1].

If, on the one hand, the perspective from which the subject was addressed in the panel at the 2012 meeting in Washington is different from Tepstra's view, on the other it is entirely complementary, since the complexity of civic republicanism in the early modern requires a plurality of observation points and analyses.

The proposal was aimed at identifying discourses about civic libertas and thus also its raison d'être, namely the government of the res publica, in fourcentury texts belonging to different literary genres: a city's history, a history of Regnum Italiae, a short political treatise dedicated to the pope who was sovereign of the city. These sources show how that specific civic discourse belongs to broader political discourses focusing the relationship between libertas and sovereignty.

For this reason the three papers are published here in the section "Sources and documents".

I would like to remember that, in preparation for the panel in Washington, on January 26, 2012 a workshop (Libertas and Res publica in early modern ) was held at the Dipartimento di Discipline storiche, Antropologiche e Geografiche. On that occasion Alessandra Mantovani, Guido Bartolucci and Angela De Benedictis submitted a draft of their future papers. The workshop was also attended by Clizia Gurreri (PhD - Università di Roma "La Sapienza": La Libertas bononiensis negli emblemi di Achille Bocchi); Irene larocci (Graduate Student - Laurea Magistrale in Scienze Storiche, 
Università di Bologna: Scrittura e riscrittura: il De republica bononiensi di Camillo Paleotti); Loredana Chines (Professor, Dipartimento di Filologia Classica e Italianistica, University of Bologna). 